\title{
Tsumura Kimiko and Resurgence of Traditional Noh Theater
}

\author{
Yasutaka Maruki ${ }^{1}$ \\ ${ }^{1}$ Department of World Languages and Literatures, Pacific University, Oregon, USA \\ Correspondence: Yasutaka Maruki, Department of World Languages and Literatures, Pacific University, Oregon, \\ USA. E-mail: wdmaruki@gmail.com
}

\author{
Received: February 18, 2013 Accepted: March 31, 2013 Online Published: June 26, 2013 \\ doi:10.5539/ach.v5n2p164 URL: http://dx.doi.org/10.5539/ach.v5n2p164
}

\begin{abstract}
This essay will introduce the biography and works of Tsumura Kimiko (1902-1975), one of the first female professional Noh actors, who threw herself into the male-dominated world and fought against the biased conventions of traditional Noh theater. Not only has she successfully opened the gates to many other female Noh actors, but more importantly, she has reevaluated the artistic value of Noh through her original Noh plays. Precisely, she highlighted the role of natural environment created by the dance accompanied with simple and familiar poetic phrases on the Noh sage. In addition, she redefined the categories of Woman Play (Kazura Mono) and of Warrior Play (Shura Mono) with the main characters in the modern context. Her biography will help us learn how Noh has come to earn its current status of a traditional art form, and explorations of her plays will broaden the canon of Noh plays.
\end{abstract}

Keywords: Noh, Japanese Theater, feminism, traditional art form, Japanese poetry

\section{Introduction}

Noh, a form of traditional Japanese theater, is one of the most mysterious and exclusive art forms today. Noh actors with masks and elaborate costumes look refined and authoritative, but their stylized movements are extremely slow, and the spoken words are, for the most part, incomprehensible as they are all in classical Japanese. In terms of Noh as a traditional art form, social and historical factors greatly affected its survival and overall value, while its artistic significance has been hidden. In contrast, when Noh was not yet traditional, early Noh actors lived modestly and were keen to promote their art as they often traveled and performed to solicit contributions toward the construction of Buddhist temples (Goto, 1989, p. 34). Zeami (1363-1443), who founded Noh with his father Kan'ami, provides a glimpse into the minds of early Noh actors, as he explains, "the purpose of the art of the $n \bar{o}$ is to serve as a means to pacify people's hearts and to move the high and low alike, which brings prosperity to all of us and promotes a long life" (1984, p. 45). Although we cannot come to know how early Noh actors used to perform, their performances must have been accessible with a sense of hospitality despite the lack of elaborate kimonos or elegant masks. For example, we are aware that Noh performances in the Middle Ages generally ran about twice as fast as today's performances (Omote \& Amano, 1992, p. 225). It was about three hundred years after Zeami's lifetime that this theatrical art form was transformed into what we know today as Noh. The costumes and the masks became standardized, improvisations in acting were discontinued, and Noh plays were modified to be slower and more ritualistic, so they would exemplify the sophistication and intelligence of the government and of the nation (Yokota-Murakami, 1997, pp. 185-189).

How can we find a way to reconcile the original Noh with the more modern "traditional" Noh? Similar to what Eric Hobsbawm explains as "the invented tradition," today's traditional Noh theater may mislead its audience by disobeying its original or historical purpose (Hobsbawm, 2003, pp. 1-3). However, despite the general idea of unbroken tradition, Noh is very much alive with fresh content and diversity. For example, since Meiji Restoration, more than three hundred Noh plays have been produced as proof of the true value of traditional art form, which does not only exist in the works of the originator but also in the efforts of continuation and progress (Nishino, 2005, pp. 1-31). Meanwhile, the truth is that it is so rare to come across a highly skilled Noh actor who has also written creative Noh plays, so that most scholarships of Noh focus on classical Noh plays and Zeami's theories. This essay will introduce the biography and the works of Tsumura Kimiko (Note 1), one of the first female and most talented modern Noh actors. Kimiko's experience will shed light on the social establishment of traditional Noh theater, and her original Noh plays will address an artistic aspect of Noh, namely, collaborative nature of the interaction between actors and audiences. 


\section{Noh as a Girl's Accomplishment}

Tsumura Kimiko was born in Akashi, near Kobe, in 1902 as the youngest child in a family of three sisters and one brother. Soon after Kimiko's birth, the family moved to Tokyo because of her father's business expansion. Kanamori Atsuko (1994) explains that Kimiko's father, Tsumura Masumi, who ran a wholesale business, was greatly devoted to his children's artistic educations: the oldest sister, Shizuko, learned Noh chanting and dancing, and the second sister, Chiyo, took private lessons from a professional Japanese-styled painter (1994, p. 7). Kimiko first followed Chiyo's footsteps and became passionate about painting, but when she was thirteen, she was told to follow Shizuko's interest after Chiyo made herself ill by staying inside her room all day and night drawing (Tsumura, 1987, p. 36). It was heartbreaking for Kimiko to give up painting, but soon she came to admire the writing of Noh plays:

From thirteen years old to seventy years old, my admiration to the beauty of Noh plays has been always in my mind. The writing is sincerely marvelous and never ceases to amaze me. The style is fairly simple, and quite frankly, it appears careless. It is all meant to leave some room for interpretation. That is why it is so deep... For example, do you remember the following lines in the classical play, Chikubu Island? "Flowers are like white snow. Until when will they fall or remain on the mountain?" Here, we read the description of the flowers falling. But actually it may not be just about the flowers, but also about the lights shining or the snowflakes swirling, or even the shimmer from the water. We are not exactly sure except something beautiful has emerged. This is an expression beyond the actual description of the scene, and it is the beauty of Noh plays (Tsumura, 1987, p. 36) (Note 2).

Kimiko associated the beauty of natural landscapes of Japanese-style paintings and that of poetic expressions of Noh plays. Both Japanese-style paintings and Noh plays promote harmonious beauty; each element of the image can be ambiguous or insignificant, but the totality of all elements is the key. As she became devoted to Noh plays, soon she developed a fascination with Noh dance and chant.

Around this time, it was not unusual for girls living in Tokyo to take lessons in Noh. According to Eric Rath (2001), "By the early twenties century, Noh dance (shimai), chanting, and musical instruments, such as the shoulder-drum, joined the list of accomplishments, including flower arrangement and tea ceremony, that young women studied prior to marriage" (p. 106). This trend was particularly fostered by the Nohgaku Association, established with the help of the imperial family in 1881 for the purpose of formally preserving the authenticity and enhancing the social value of traditional Japanese theater (Note 3). It was also during this time of the Sino-Japanese War (1894-5) and the Russo-Japanese War (1904-5) that Noh came to embody the nation's social purpose. Rath (2004) explains, in 1902, as an attempt of the Nohgaku Association's "ultra-nationalism," a Noh stage was placed at "the Yasukuni Shrine, the memorial for the nation's war dead," for regular performances viewed by members of the imperial family and the general public (p. 224). Tamura Keiko (2007) explains a vocabulary shift in the newspapers and magazines of the time, which ceased to describe Noh as "a traditional art form" and began to describe it as "a national art form" and "an imperial art form" (p. 145). Moreover, Noh plays of national propaganda about battles and victories against other countries were actively produced (Note 4$)$. When the role of Noh was artificially shifted away from cultural and artistic values, the Nohgaku Association instantly gained recognition as an organization that signified the power of the Japanese spirit.

Meanwhile, despite their rather active involvement in learning Noh, women remained excluded from professional productions. Here, Ito Maki (1991) lists publicly acknowledged rules at that time:

1) Women are not allowed on the Noh stage under any circumstance.

2) Women are not allowed to participate in the full-scale performance of Noh play even outside the Noh theater.

3) Women are only allowed to dance, chant, and play Noh instruments independently outside the Noh theater (p. 249).

Although women were entitled to learn and therefore provide an important source of income to Noh actors, they were prohibited from showing their achievements in public. This was clearly different from other traditional art forms, such as flower arrangement and tea ceremony, which allowed women to become professional in the early years of the Meiji period. The most common criticism of a female Noh actor is that it is a physical art form, so a particular body type and a masculine voice are required to master the art. However, the actual reason is due to commonly accepted notions of gender territory. The Noh stage, where a battle scene can be reenacted or the spirit of a dead warrior returns for salvation, must be placed far away from the domestic realm (Note 5). Thus, even though women were encouraged to learn Noh chant and dance as a way to educate themselves before 
marriage, they could not set their feet on the "sacred" Noh stage. On the other hand, flower arrangement and tea ceremony are domestically practiced arts that women were able to access and explore rather freely. When she began to learn Noh, Kimiko was probably not aware of such unfairness and prejudice. Her determination to perform on the Noh stage eventually caused her countless hardships when she faced oppression and discrimination.

\section{Performance in Korea and the Ataka Incident}

When Kimiko was seventeen years old, her life took a drastic turn. Because her father's business hit a financial crisis, Kimiko secretly began teaching Noh chant and simple movements of Noh dance to the local children to support her family financially but also to pay for her own lessons (Kanamori, 1994, p. 116). Fortunately, she became a student of Kanze Kasetsu (1884-1959), one of the most established Noh actors of the modern time. Kasetsu was the first son of a famous Noh actor, Kanze Kōsetsu (1843-1911), the head of the Kanze school that dates back to the fourteenth century. In addition, Kasetsu's mother was a niece of Umewaka Minoru (1828-1909), who performed for the Meiji Emperor and Iwakura Tomomi in an effort to garner imperial support. Kasetsu followed in his father's footsteps and became a professional Noh actor and the head of the Kanze school. This is a typical practice of the Iemoto system: the first son in each generation is responsible for carrying on the tradition of the family's art form. This family-based, heredity system is especially important for Noh, as it is an enterprise that involves various professions. In order to perform a Noh play, one has to rent the Noh stage, borrow appropriate costumes and masks that are often the owners' family treasures, arrange schedules with several other Noh actors and the musicians, and finally spend a large amount of money for publicity. It is a tremendous advantage to be born into a Noh family in order to use the network that has been passed down over generations. Kimiko had none of these connections. Nonetheless, Kimiko devoted herself thoroughly to the art of Noh, memorizing all two hundred classical Noh plays by heart and improving her skills dramatically under Kasetsu's instruction (Tsumura, 1987, p. 43).

One day, Kimiko heard about an opportunity to earn substantial amount of money from her former fellow student named Kim Donq-Wan: it was to travel to Korea and provide Noh lessons, not to children but to wealthy adults (Tsumura, 1987, p. 43). At that time, Korea was under Japanese occupation, and major cities were filled with Japanese businessmen. Among them, Noh became a popular, intellectual hobby, but Kanamori (1994) explains that no professional Noh actors were willing to travel to Korea, where anti-Japanese sentiment was strong (p. 42). Remarkably, Kimiko convinced her family that she would travel to Korea by herself, and her life as a travel Noh instructor started. Soon she became popular among many enthusiastic students and came to have several well-trained students of her own. As she built her reputation as a skilled instructor in Korea, she then entered a forbidden territory. Encouraged and flattered by her students, she and her students stepped onto the stage and performed Hagoromo, a famous Noh play about a heavenly maiden (Figure 1) on the temporarily modified stage, which was far from authentic, but this became her first Noh performance. She was just nineteen years old.

Because a young girl from Japan was performing a Noh play openly on the stage, a newspaper reporter wrote about the event and mistakenly introduced Kimiko as a leading disciple of a famous Noh actor, Kanze Kasetsu, even though she was just one of his many amateur students (Kanamori, 1994, p. 52). Not surprisingly, the members of the Nohgaku Association were shocked - first to discover that a woman had performed before an audience, and second to learn that it appeared as though Kasetsu had approved of his female student's onstage performance. Kimiko was ordered not to have any contact with the Nohgaku Association, and the master-disciple relationship between Kasetsu and Kimiko abruptly came to an end (Kanamori, 1994, p. 53). Seeing his younger sister's struggle, Kimiko's older brother, Tsumura Kyōson, a scriptwriter of modern drama, encouraged her to change her path (Tsumura, 1987, p. 41). Despite his advice and the Nohgaku Association's prohibition of her work, Kimiko did not give up her dream:

There was nothing else I could do, except learning Noh through my eyes, so I went to see as many Noh performances as possible. It did not matter which school or organization held the performance... I took detail notes not only on movements and gestures of actors, but also on stage props, masks, and costumes... Sadly, I could not see what was happening behind the curtain, for example, how the actors wore the costumes and so on. So I often sat behind the chorus and tried to peek inside the green room (Tsumura, 1987, p. 40). 


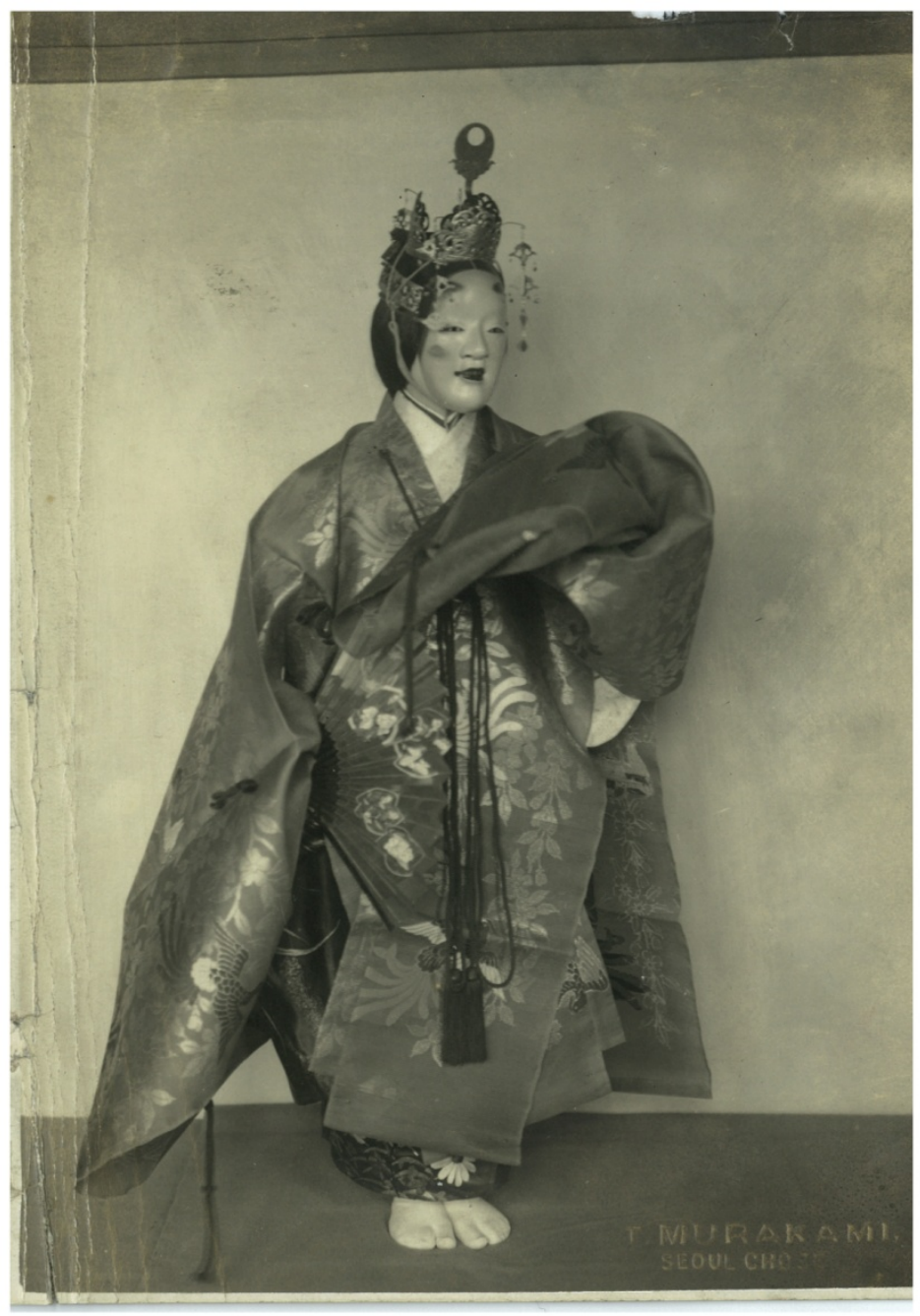

Figure 1. Tsumura Kimiko wearing the costume of Hagoromo in Soul (Photographed by Anonymous, 1920)

Kimiko's objective was to learn every aspect of Noh, master it, and teach it to her students, so that she would be able to perform again with her students. In 1925, four years after her first performance in Korea, Kimiko established her own school called Ryokusen-Kai. It was certainly illegitimate from the perspective of the Nohgaku Association, but she made a clear statement to express her belief that "Noh is an art form for everyone under the heaven, not limited for those with certain body types and faces" (Tsumura, 1987, p. 50).

However, no matter how diligently Kimiko trained herself and her young pupils, she still faced apparent obstacles. If they were actually going to perform, how could they rent a Noh stage, costumes, and - most problematically_-masks? Thankfully, Hashioka Kiutaro, a renowned Noh actor and a student of Kasetsu's father, bravely allowed Kimiko to use his Noh stage, and Kimiko even received aid from tailors, who created Noh costumes and made stage props (Tsumura, 1987, p. 40). One day, Sakamoto Settcho (1943), a famous critic of Noh, came to observe one of Kimiko's performances and published his review in the national newspaper:

I went to see Tsumura Kimiko's performance of Yashima. She trained the musicians, the waki actor, and the chorus all by herself without any outside collaborators or professionals. In such case, new or unique ideas are inevitably presented. However, her performance was strictly faithful to the conventional style. Her effort to follow the tradition is certainly impressive. She was better as the latter shite, (playing the role of a powerful warrior). Despite her short height, she admirably performed well with fine skills (p. 188).

Even though Kimiko was just an amateur performer of whom the Nohgaku Association disapproved, Sakamoto's words were a tremendous encouragement to her, and gradually Kimiko cultivated a strong reputation. 
In December 1939, Kimiko prepared to perform Ataka with her students. It was provocative to attempt such a popular masculine play that used no masks. Kimiko's role was Benkei, Japan's nationally recognized hero, who personifies loyalty, wisdom, and power. However, a day before the performance, Kiutaro became seriously ill in Nagoya, and because of his absence, the owners of the costumes, who had previously agreed to lend them, reneged on their agreement (Tsumura, 1987, p. 48). Kimiko was crushed and her students were devastated and completely at a loss as the audience gathered in the theater. Kimiko explains what happened next:

Suddenly, I ran to the stage, wearing my regular hakama (the traditional style of everyday clothes) and expressed my frustration to the audience on the stage. I begged to know why Noh was the only traditional art form that had not yet allowed women. I spoke about the unfairness of the Nohgaku Association for about an hour. Then, afterward, my students and I performed Ataka with no special costumes. We all performed just with regular hakama. It is amazing what youthful enthusiasm can do (Tsumura, 1987, p. 49).

It is important to highlight the fact that rather than giving up performing and apologizing to the audience, Kimiko and her students performed Ataka without elaborate and expensive costumes. This was a defining moment that crystallized how Kimiko fell in love with the writing of Noh plays and continued to pursue her dream to perform on the Noh stage. Not being born in the family of professional Noh actors, Kimiko needed to prove her worthiness only by her skills in Noh, just like early Noh actors in the Middle Ages. In fact, at the performance of Ataka, Kimiko and her students, in a way, demonstrated how early Noh actors used to perform with simple costumes in the Middle Ages.

\section{Kimiko's Noh Plays}

Kimiko always insisted her strength and determination came from her desire to express the literary beauty of Noh plays onstage. In the following, she provides her interpretation of the intricate relationship between language and dance (Figure 2):

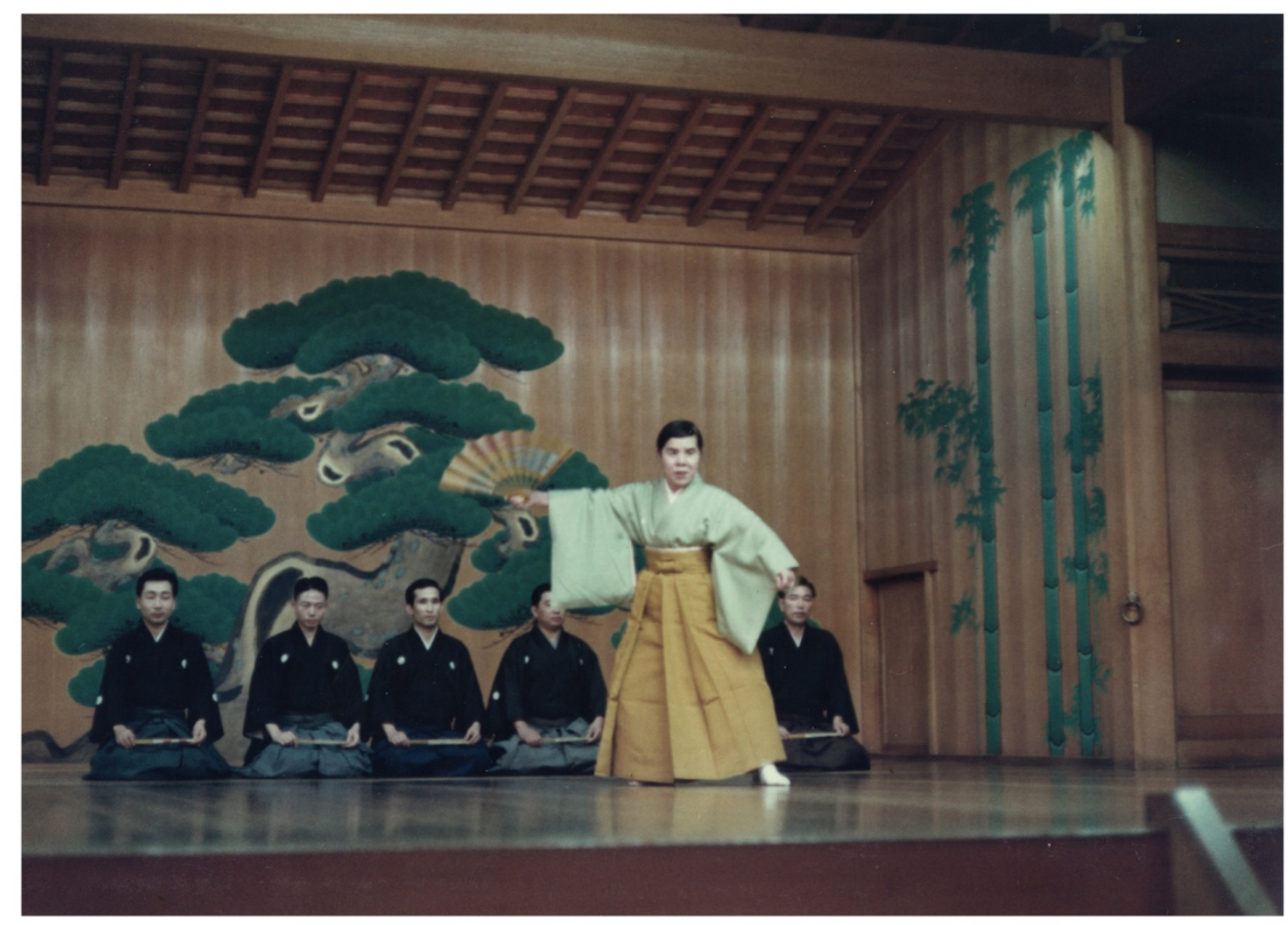

Figure 2. Tsumura Kimiko, Noh Dance (shimai) Takasago at Ryokusen-kai, Tokyo (Photographed by Morita Toshiro, 1971) 
Noh is after all poetry. The air that the poem exhales and the mind that wears a veil called poetry-they are the beauty, the strength, and the vast expanse of my soul. It is my true being detached from my body. And quietly, I see myself, my whole body, front and back, tip of my toes, and what surrounds me. It is the field where I stand under the clouds. And they are all transparent. That is Noh and the heart of Noh. On the stage, I chase illusions and dance the scenery (Tsumura, 1987, p. 36).

Kimiko confirms that the movement of the actors helps to create the environment on the bare Noh stage. In return, the audience's role is to visualize the image through watching the dance and listening to the chant, that is, the poetic expression of natural scenery. Therefore, as the language needs to be accessible, Kimiko's plays are written mainly in modern Japanese language, and classical words are all familiar poetic phrases. To investigate how Kimiko articulated this idea in her own plays, her two plays of different genres-Akino No (Autumn Field) in the category of Woman Play (Kazura Mono) and Koromo no Tate (Shield of Robe) in the category of Warrior Play (Shura Mono) — will be analyzed.

Akino No features Lady Nukata (Nukata no Ōkimi), an aristocratic poet whose poems are included in Man'yōshū, Japan's oldest anthology of poetry. She was also a wife of Emperor Tenmu (631-686), but it is said that she had a secret affair with Emperor Tenji (626-671). The details of her life are unknown, and there is no classical Noh play about her either. For the base of Akino No, Kimiko used the following poem by Lady Nukata compilied in Man' $y \overline{o s h} \bar{u}$ (1:8): "In the autumn field of Uji, the grass was cut for a temporary lodging. I miss the time of staying under the grass roof" (Mori, 1992, p. 3). Lady Nukata remembers her experience of spending a night away from the capital with other members of the imperial family, to which Edwin Cranston (1993) comments that there is "a sense of immediacy and awed anticipation (p. 174). In the beginning of Akino No, a traveling priest, performed by the waki actor, introduces himself to the audience:

Waki: The clouds are accompanying me throughout my trip. The clouds that are accompanying me wander above in the end of the autumn field. I am a traveling priest. When the autumn had reached its halfway point, I left my hermitage made of brushwood. I have been making a pilgrimage to historically known places, and my next destination is Uji Yamada (Tsumura, 1987, p. 8).

Followed by the traveling priest, who has just arrived in Uji Yamada, two local women, performed by the shite and the tsure actors, appear:

Shite \& Tsure: As we pull the cart of freshly gathered plants, the moon shines gently on our hands. In the autumn night, when our mind is deepened, we will be staying in the hut made of grass. The time has come to immerse ourselves in thought ... Somewhere, under the long bowing grass, insects are chirping. It is the presence from the past, our unforgotten hut of pampas grass. Searching for the clouds, the clear shadow of the autumn moon appears (Tsumura, 1987, p. 8).

Kimiko creates an impressionistic atmosphere with the appearance of the flower-pickers, who are in fact ghosts of Lady Nukata and her servant. This is the conventional beginning of many popular classical Noh plays: a traveling priest arrives at a rural place and encounters a local who is in fact a historical individual whose restless soul has remained in this world. As for the category of Woman Play, the main character usually represents an unforgettable love and strong attachment to her lover.

Next, the priest asks the flower-pickers whether they know of some place where he can stay at tonight, and they gladly suggest the hut made of grass, telling the old story of the emperor's visit to this place. The priest is delighted, but wonders why the hut looks new. One of the flower-pickers then suddenly leaves the stage.

Waki: It is certainly odd. She appeared to be blanched all of a sudden, and her tears were rolling down her sleeve as she walks away.

Tsure: I must confess to you remorsefully. I am a servant of Lady Nukata who lived many years ago. She has fallen into a delusion, so please let her be free.

Waki: Is it because of her attachment that she still remains in this world?

Tsure: Two gentlemen are pulling her right sleeve and left sleeve from the opposite side. Being lost, she stands still in the field, as the wind continues to blow through the grass (Tsumura, 1987, p. 9).

The servant describes a powerful image of Lady Nukata being anchored in the field, and the priest agrees to offer a prayer so that she and her servant can both peacefully leave this world. When the shite actor returns the stage as a ghost of Lady Nukata, she chants another poem written by Lady Nukata in Man'yōsh $\bar{u}, 1: 20$ : "Under the evening sun, I have come to the purple field. Please do not wave at me, the guard may be looking at you" (Mori, 1992, p. 6). The ghost of Lady Nukata then dances to express her nostalgic love, yet the chants during the dance are exceptionally short, and the audience only hears that suddenly the rain begins to fall. After the final dance by 
the ghost of Lady Nukata, the chorus then chants as she again leaves the stage. This is the concluding section of the play:

Chorus: Blowing and blowing, the wind pushes its way in the meadow. Dews on pampas grasses are sprinkled like falling tears. The moonlight reflects on the wet sleeve, shining like jewels of gold and silver. Under the shining lights, her emotions overflow. She beats her sleeve, but the wind carries the water right back. The night falls, as the delusory attachment appear in her shallow dream. The geese above fly away to the clouds, and their distant cry echoes in the dark autumn night. Fading away into the bushes, fading away into the bushes, just a shadow of Lady Nukata remains on the grass (Tsumura, 1987, p. 10).

This ending is simple and straightforward. Usually the chorus provides an explanation that goes beyond describing how the leading character leaves the scene-for example, how she has found or has not found salvation after the priest provided a ritual service. Moreover, one of the most popular endings is that the priest wakes up in the morning and realizes that everything he experienced was a dream. These additional developments of the story are all omitted in Akino No. In the play's conclusion, Kimiko concentrates just on the scene of the ghost of Lady Nukata disappearing into the darkness, ending with the lingering imagery of the dramatic scenery.

Similar to conventional Noh plays of the Woman Play genre such as Izutsu and Matsukaze, Akino No shows the soul of the heroine remaining in this world, and the natural surrounding magnifies her loneliness. However, unlike Izutsu or Matsukaze, Akino No places less emphasis on the heroine's past with her lover. Usually in a Woman Play, the heroine expresses her sincere obedience and desperation to reunite with her male lover, as her attachment has prevented her from moving onto the next phase of life. The heroine of Izutsu, for example, is so considerate of her husband that she worries for his safety as he travels at night to see his mistress. This is, as Wakita Haruko (2005) points out, clearly "an idealized woman produced by men" (p. xii). On the contrary, no name or memento of her lover is introduced in Akino No, and the heroine does not express her vulnerability or desire to reunite with her lover either. Although there are other poems written by Lady Nukata in which she expresses her deep sorrow in missing her lover, Kimiko chose the poems particularly for their pastoral descriptions and avoided creating an empathetic character. Rather than portraying beauty through an unnatural woman, Kimiko focused on how the condition of the surroundings has transformed in the end, reflecting the main character's emotions.

Unlike the dark and sorrowful scenery of Akino No, cheerful and peaceful scenery is presented in Kimiko's Warrior Play, Koromo no Tate. This play is based on the battle of Minamoto no Yoshiie (1039-1106) by the Koromo River in the northern rural area of the current Iwate prefecture. This incident is described in the classical text, Kokon Chomonju:

When a great warrior, Yoshiie, chased down and was finally about to defeat Sadatō near the Koromo River, Yoshiie read a poem saying that Sadatō's Koromo Castle would be destroyed completely. The word 'koromo' means both the name of the place and 'clothing,' so Sadatō improvised a poem saying that his clothing came apart at the seams after many years of the battle. Impressed by Sadatō's poem, Yoshiie allowed him to escape (Nagazumi, 1974, p. 272).

Koromo no Tate carries on this central message that the poetry moves even a warrior's heart and portrays the beautiful setting of the Koromo River. In the beginning, a traveling priest, the waki actor, appears and introduces himself.

Waki: On the water that carries away flowers, on the water that carries away flowers, the moon is reflected dimly. This is a priest traveling from the West. As I had not seen the East, I left my home to go on a pilgrimage. I continued my path even to the deep North and came across this river that the locals call the Koromo River. Surely, this is a view that reminds me of old days. The faint moon is already up in the sky, and a haze lay over the river. Small boats with poles look like little birds on the water. Somehow they do not appear to be coming closer as if they are waiting for me upstream (Tsumura, 1987, p. 11).

Followed by the priest, old men, played by the shite and the tsure actors, appear on the stage.

Shite: "The moonlight is reflecting on the stones of a ford." "Little birds are singing and returning home."

Tsure: "River water carries away the spring, as if it is going to wash away completely."

Shite: "Availing themselves of the beauty of the moon, people return home." 
Shite \& Tsure: Surely, it is a touching sight.

Shite: Oh, lush trees covered in moss are handing over the water. The thatched area is covered with flowers.

Shite \& Tsure: In the hazy spring night, the boats, floating on the current, hurry home with a song of rowing the pole. The moon is calm above us. "Even any heartless person can feel deeply the pathos of life" (Note 6). Plum trees and cherry trees, some bloom early and others bloom late. The full bloom in succession, the full bloom in succession. Under the faint light on the river, the spring breeze slowly blows. The flowers lay scattered on the water carrying the fragrance with them and look like sparkling lights of the moon or the white pearls. Oh, the wet and floating garments of the flowers, the wet and floating garments of the flowers (Tsumura, 1987, p. 11).

Kimiko creates perspective scenery. First, using the priest's point of view, the scene in the far distance of the moon and the river is described. Second, the view of the close distance of the boats, the people, and the flowers is introduced. Moreover, for the lines of the old men, the shite and the tsure actors, Kimiko quotes poetic lines from famous classical Chinese and Japanese poems and incorporates various poetic lines to provide multiple layers of meaning and representation.

When the priest and the old men come face to face, the priest asks why there is a bow placed on the side of the road, and then the old man tells the story of the poetic exchange between Yoshiie and Sadatō at the Koromo River. At the end of the story, the old man confesses that he is the ghost of Yoshiie and leaves the stage. The priest decides to recite a sutra to show his respect, and the shite actor dressed in a colorful suit of armor, returns to the stage.

Chorus: The time is mid autumn. The surface of rice fields in all direction has changed its color. The autumn wind blows, making the golden waive all around. Where the wind is headed, the enemy warriors appear, and I proceed with my horse.

Shite: This is fascinating. Now is the time!

Chorus: A group of wild goose was lined up quietly but all of a sudden flew off and disappeared into the sky. It is strange. The force is actually all around the field. Overpowering the enemy from all directions, remarkably, this man brought peace to the four seas. The man is indeed Yoshiie, who once ruled the entire land. Now as a divine spirit, he protects the whole nation. The voice of defeated evil spirits echoes in the sky.

Shite: Demons and fierce spirits, make sure you all listen carefully. Our nation, Japan, is a small country but is steady protected by divine grace. There is no place for you at all.

Chorus: The divine voice is heard. The divine bow is exhibited. The divine voice is heard, and the divine bow is exhibited. The bowstring makes a sharp sound, and an arrow is released to the dark clouds. The voices of demons echo, as they try to escape and fly away in a thousand different directions. The arrows are shot and shot. The trails of clouds appear in the sky. The morning wind blows, the cherry blossom is fragrant, and the shadow of the willow at the eaves becomes clearer. The sun rises, and the shadows appear. Under the brightening sky, this dreamy spectacle slowly comes to an end (Tsumura, 1987, p. 14).

This is a unique ending compared to conventional Noh plays of the category of Warrior Play. Normally, just as in Atsumori or Tadanori, the soul of the deceased warrior expresses anger, regret, or anger, as it is the very reason that the soul has not found peace and has appeared in front of the traveling priest. Thus, typically, the final dance is a reenactment of the battle scene or of the experience of the warrior's suffering in hell. Even in Ebira or Yashima, which highlights the victory of the leading character in the battle, the Shurado (the Realm of Warrior Gods: one of six realms in the Buddhist cosmology) is addressed to show the afterlife struggles of the warrior. On the contrary, no negative emotions are expressed in Koromo no Tate, and Kimiko concludes with a powerful image of Yoshiie demonstrating his strength and defeating his enemy. The fact that Yoshiie is the guardian deity of Japan ironically implies a connection with the propaganda Noh plays in the early twentieth century. Yet, the ambiguity of the enemy highlights the glorification of Yoshiie without any sense of animosity, and his celebratory posture represents nothing but the splendor of the location.

\section{Conclusion}

Today, the situation in regards to professional female Noh actors is completely different from Kimiko's time. There are about fifteen hundred professional Noh actors registered at the Nohgaku Association and over two 
hundred actors are female. As an art form that signified Nationalism and Imperialism in the first half of the twentieth century, Noh became not only an educational art form, but also a social and even political art form, and after the WWII, it became an important cultural and historical icon both domestically and internationally. However, it seems that the challenge for Noh actors has been fairly consistent in the last hundred years, that is, how Noh can be appreciated artistically in addition to being a traditional art form. As Karen Brazell (1998) describes that the creativity of Noh actors is "more comparable to that of musicians than to Western-style actors," as far as the performance goes, there is no need to negate or change the tradition in an apparent manner for Noh actors, because only by following the predetermined rules, paradoxically, they can express their originalities ( $\mathrm{p}$. 124). Kimiko discusses the individual nature of Noh dance:

When I dance, there should not be any part of myself recognized as if I am performing some conventional form. Transcending the form and forgetting everything including my arms and legs or any thought of how I am perceived, I become true to myself and able to dance. Then how or what should I dance? It is purely based on my reading of Noh plays, my own interpretations after many hours of reading to myself. That is why the true master in the art of Noh is actually the writing of Noh plays (Tsumura 1987, p. 36).

This account sounds surprisingly liberal for Noh actors who are required to master specific skills and techniques. The point is that each Noh actor's artistic spirit comes from inner understanding of the Noh play, as the body of the actor becomes an instrument for the audience's imagination on the stage. Here, the accessibility of the language and the familiarity of a character play important roles for the audience to visualize the scene. Therefore, in spite of Kimiko's strong admiration of classical Noh plays, her poetic phrases are much simpler and precise, and the main characters of her plays are modified for the modern audiences - a realistic and more independent female character in Akino No and a warrior with a sense of celebration and spiritual consent in Koromo no Tate. In Kimiko's mind, the leading character does not simply tell or reenact a story, but creates a theatrically shared space with the audience. This is the way Noh continues to thrive as a traditional yet modernized art form.

\section{References}

Brazell, K., \& Araki, J. (1998). Traditional Japanese Theater: An Anthology of Plays. New York: Columbia University Press.

Cranston, E. (1993). A Waka Anthology - Volume One: The Gem-Glistening Cup. Stanford: Stanford University Press.

Goto, H. (1989). Noh no Keisei to Zeami. Tokyo: Mokuji Sha.

Hobsbawm, E., \& Ranger, T. (1992). The Invention of Tradition. Cambridge: Cambridge University Press.

Ito, M. (1991). Joryu Noh no Paionia - Tsumura Kimiko no Seishun. In T. Engekikai (Ed.), Taisho no Engeki to Toshi. Tokyo: Musashino Shobo.

Kanamori, A. (1994). Joryū Tanjō: Nougakushi Tsumura Kimiko no Shōgai. Tokyo: Housei Daigaku Shuppan Kyoku.

Mori, J. (1992). Man'yōshū. Tokyo: Kasama Shoin.

Nagazumi, Y., \& Shimada, I. (1974). Kokon Chomon Ju. Tokyo: Iwanami Shoten.

Nishino, H. (2005). Shinsaku Noh no Hyakunen 1904-2004. Nohgaku Kenkyu, 29, 112-142. Retrieved from http://repo.lib.hosei.ac.jp/bitstream/10114/1312/1/nogaku_29_nishino.pdf

Omote, A., \& Amano, F. (1992). Iwanami Kōza, Noh Kyogen (1) Nohgaku no Rekishi. Tokyo: Iwanami Shoten.

Rath, E. (2001). Challenging the Old Men: A Brief History of Women in Noh Theater. Women and Performance: A Journal of Feminist Theory, 12(1), 97-111,

Rath, E. (2004). The Ethos of Noh. Cambridge: Harvard University Asia Center.

Sakamoto, S. (1943). Tadashii Gei ha Tōtoi. Sakamoto Settcho Nohyo Zenshu (Vol. 2).Tokyo: Unebi Shobō.

Tamura, K. (2007). Kindai ni okeru Nohgaku Hyōshō. Development of Research and Study Methodologies in Theatre, 9, 143-150. Retrieved from http://hdl.handle.net/2065/26937

Tsumura, K. (1987). In R. Tsumura (Ed.), Chirikuru Hanani. Tokyo: Ryokusen-Kai.

Wakita, H. (2005). Nohgaku no nakano Onnatachi. Tokyo: Iwanami Shoten.

Yokota-Murakami, G. (1997). The Formation of the Canon of Nō: The Literary Tradition of Divine Authority. Osaka: Osaka University Press. 
Zeami. (1984). In T. Rimer, \& M. Yamazaki (Tr. \& Ed.), On the Art of the No Drama. Princeton: Princeton University Press.

\section{Notes}

Note 1. For Japanese names, the author followed the Japanese order of family name followed by given name throughout the text. For actors' names, either the complete name or the given name is used.

Note 2. All citations from Japanese sources are translated by the author.

Note 3. The well-known story of the revival of Noh involves a statesman, Iwakura Tomomi, and Empress Dowager Eishō. Encouraged by a former president of the United States, Ulysses Grant, Iwakura decided to preserve and support Noh and Kyogen as nationally iconic art forms equivalent to Western opera. Empress Dowager Eishō and Iwakura became prominent patrons of Noh and Kyogen actors, and they were joined by many noble families who were the descendants of aristocratic families during the Edo period.

Note 4. Nishino (2005) introduces following propaganda plays; in Takachiho, written by Koike Yasukazu, a sacred hawk appears at the victorious battleship in the Sino-Japanese War and kills a violent eagle that represents the enemy; in Washi (Eagle), written by the famous poet and scholar Owada Yakeki, the eagle symbolizes Russia and is killed by the reincarnation of the legendary warrior of the Middle Ages, Minamoto no Yoshitsune; and in Ikusa Gami, written by Hirota Kazuki, a great real-life soldier, Hirose Takeo, becomes a godly figure after the victory over Russia.

Note 5. This restriction is similar to the way in which women are still prohibited from the professional sumo ring $($ dohyo $)$. For example, when a woman holding fliers in her hand tried to climb up the sumo ring during a tournament, the incident became a national news story on September 20,2007. The content of the flier was never revealed.

Note 6. The line of the shite actor is a combination of the phrases from the poem, "Taking a boat down to Kui Zhou but because of the rain, unable to say good bye to my fellow general" by Du Fu and "A night-vigil in the left court of the palace," also by Du Fu. The next line of the tsure and the following line of the shite are from "Spring moonlight on the flowers by the river" by Zhang Ruoxu. The quoted phrase in the chant by the shite and the tsure is from Saigyo's Sanka Shu, number 470.

\section{Copyrights}

Copyright for this article is retained by the author(s), with first publication rights granted to the journal.

This is an open-access article distributed under the terms and conditions of the Creative Commons Attribution license (http://creativecommons.org/licenses/by/3.0/). 